\title{
A survey of the combined effects of waterlogging and salinity on fruit yield in the date palm groves of the Wargla basin, Algeria
}

\author{
Mustapha DAdDi BouHoun ${ }^{1}$, Serge MARLET ${ }^{2 *}$, Louhichi BrinIs ${ }^{3}$, Mohamed LaKHDAR SAKER ${ }^{1}$, Jacques RABIER ${ }^{4}$, Marc CôtE ${ }^{5}$
}

\author{
${ }^{1}$ Univ. Kasdi Merbah Ouargla, \\ Lab. Prot. Ecosyst. Zones Arid. \\ Semi-arid., \\ BP 511, Ouargla 30000, \\ Algérie \\ ${ }^{2}$ CIRAD-ES, UMR G-EAU, \\ TA 73 / 09 , \\ 34398 Montpellier Cedex 5, \\ France \\ serge.marlet@cirad.fr \\ ${ }^{3}$ Univ. Badji Mokhtar Annaba, \\ Lab. Biol. Vég. Environ., \\ BP 12, Annaba 23000, \\ Algérie \\ ${ }^{4}$ Univ. Provence \\ (Aix-Marseille 1), \\ Cent. Sci. Saint-Charles, \\ Equipe Biodivers. Environ.,
}

case 17, 3 place Victor Hugo,

13331 Marseille Cedex 3,

France

\section{${ }^{5}$ Univ. Provence}

(Aix-Marseille 1),

UFR Géogr. Aménag.,

Les Jourdans,

84240 Cabrières-d'Aigues,

France

${ }^{*}$ Correspondence and reprints

Received 24 March 2010

Accepted 17 May 2010

Fruits, 2011, vol. 66, p. 11-24

(C) 2011 Cirad/EDP Sciences

All rights reserved

DOI: 10.1051/fruits/2010037

www.fruits-journal.org

RESUMEN ESPAÑOL, p. 24

\section{A survey of the combined effects of waterlogging and salinity on fruit yield in the date palm groves of the Wargla basin, Algeria.}

\begin{abstract}
Introduction. While researchers have paid considerable attention to the effect of soil salinity on crop yield, methodological impediments remain when salinity is combined with other growth factors, especially in farmers' fields. A specific methodology was adapted to assess the effect of waterlogging and salinity on date palm yield (Phoenix dactylifera L. cv. Deglet Noor). Materials and methods. Date palm yield, water table depth, irrigation water, groundwater and soil salinity were measured in 167 field plots located in five irrigation sectors of the Wargla basin (Algeria). Variance analysis and a boundary line approach were combined to analyze actual and potential yields according to environmental stresses. Results and discussion. High soil salinity resulted from saline irrigation water and a shallow water table. Actual yield decreased with the increase in soil salinity, the decrease in water table depth, and the presence of a gypsum-cemented horizon within the soil profile. The significant effect of the interaction between water table depth and soil salinity showed that the crop responded to the most severe stress rather than to combinations of the individual effects. Potential yield was assessed according to classes of water table depth, soil salinity and the occurrence of a gypsum-cemented horizon. The relationship between soil salinity and potential yield was calibrated according to two models. The limiting factors in order of decreasing importance were shallow water table, high soil salinity and occurrence of a gypsum-cemented horizon for $38.3 \%, 16.8 \%$ and $2.4 \%$ of the field plots, respectively; there was no limiting factor for $42.5 \%$ of the field plots. In certain sectors, actual yields remained far below potential yields and the additional effect of irrigation water salinity could thus be considered.
\end{abstract}

Algeria / Pboenix dactylifera / yields / waterlogging / soil salinity

Enquête sur les effets combinés de l'engorgement et de la salinité sur le rendement des palmeraies du bassin d'Ouargla, en Algérie.

Résumé - Introduction. Alors que les chercheurs ont porté une très grande attention à l'effet de la salinité du sol sur le rendement des cultures, des obstacles méthodologiques demeurent lorsque la salinité est combinée à d'autres facteurs de croissance, en particulier en conditions réelles dans les parcelles des agriculteurs. Une méthodologie spécifique a été adaptée pour évaluer l'effet de l'engorgement et de la salinité sur le rendement du palmier dattier (Phoenix dactylifera L. cv. Deglet Nour). Matériel et méthodes. Le rendement du palmier dattier, la profondeur de la nappe phréatique, l'eau d'irrigation, les eaux souterraines et la salinité du sol ont été mesurés dans 167 parcelles situées dans cinq secteurs d'irrigation du bassin d'Ouargla (Algérie). Une analyse de variance et une approche par la méthode des courbes-enveloppes ont été combinées pour évaluer les rendements réels et potentiels en fonction des contraintes environnementales. Résultats et discussion. La forte salinité des sols est la conséquence de la salinité de l'eau d'irrigation et de la faible profondeur de la nappe phréatique. Le rendement réel a diminué avec l'augmentation de la salinité des sols, la diminution de la profondeur de la nappe, et la présence d'un horizon gypseux compact dans le profil pédologique. L'effet significatif de l'interaction entre la profondeur de la nappe phréatique et la salinité des sols a montré que la culture répondait davantage au stress le plus sévère qu'à la combinaison des effets individuels. Le rendement potentiel a été évalué en fonction des classes de profondeur de la nappe phréatique, de la salinité du sol et de la présence de l'horizon gypseux compact. La relation entre la salinité du sol et le rendement potentiel a été calibrée en fonction de deux modèles. Les facteurs limitants ont été, dans l'ordre d'importance décroissante, la nappe phréatique peu profonde $(38,3 \%$ des parcelles étudiées), la forte salinité du sol (16,8\%) et la présence d'un horizon gypseux compact (2,4\%); il n'y a pas eu de facteur limitant pour $42,5 \%$ des parcelles. Dans certains secteurs, les rendements réels sont restés nettement inférieurs aux rendements potentiels et l'effet supplémentaire de la salinité de l'eau d'irrigation pourrait donc être envisagé.

Algérie / Phoenix dactylifera / rendement / engorgement du sol / salinité du sol 


\section{Introduction}

Today up to 300 Mha of land are irrigated, representing $18 \%$ of cultivated land worldwide, and this land produces about $40 \%$ of the food in the world. Approximately 77 Mha are affected by salinity, i.e., $28 \%$ of the irrigated area, including $15 \%$ severely or very severely affected, and half of the existing irrigation systems are considered to be threatened to varying degrees. Salinization is the consequence of various complex processes of salt redistribution that depend on natural conditions, system features, agricultural practices, and irrigation and drainage management. Salinization is due to saline irrigation water, agricultural water management, or the mobilization of the fossil salt content of the soil or of the aquifer in areas with limited drainage [1]. The increase in salinization has resulted in about 50 Mha of irrigated land being equipped with drainage systems to prevent waterlogging and soil salinity. With the considerable expansion of irrigation and drainage, land salinization has become a major threat to the viability of many irrigation systems [2].

During the past 100 years, many studies have been carried out to investigate the tolerance or sensitivity of crops to salinity. Maas and Hoffman conducted an analysis of the data [3], which was subsequently updated by Maas [4]. They concluded that the influence of root zone salinity on crop yield can be reasonably described by a piecewise linear relationship characterized by a salinity threshold below which yield is not affected, and above which yield decreases linearly with an increase in salinity. An alternative S-shaped response model provided an equally good fit to many experimental data sets [5]. FAO published an extensive list of crop salt tolerance data [6]. Each crop was classified into four main groups: sensitive, moderately sensitive, moderately tolerant, and tolerant to salinity. Date palm is considered as one of the most tolerant crops to salinity. However, these data were based on simplifications where root zone salinity was regarded independently of water management, and unless any other growth factors were considered. Beyond these experimental bases and empirical relationships, tolerance to salinity is the result of a set of physiological mechanisms with complex genetic determinism and osmotic, ionic and nutritional effects that interact with each other [7]. In the short term, osmotic effects are predominant and interactions with water stress are significant. In the longer term, effects result more specifically from the accumulation of excess toxic ions in the plant.

Most functional relationships have been established from experiments conducted in a controlled environment. In real conditions in farmers' fields, yields are generally lower than expected under the influence of a combination of factors, and it is often difficult to define a precise salinity threshold from erratic data sets and a limited number of observations [8]. This is particularly the case when two factors, such as salinity and water stress, are likely to interact, amplifying the expected single effect of salinity [9]. Moreover, the distribution of salts in the soil is neither homogeneous nor stationary, and the effects of salinity may vary depending on the developmental stage of the crop [10]. Finally, a wide range of agronomic and environmental factors is also liable to jointly affect crop yields. Diagrams, correlations, multiple linear regression and non-linear models are commonly used to study the relationships between environmental factors and crop yields. Nevertheless, these approaches assume that the factors are independent of one another. In the cloud of data, correlations indicating a decrease in yield with increasing salinity are often significant, but the models generally do not explain yields satisfactorily [11].

The principle of the boundary line approach was described by Webb [12], and subsequently applied to describe the effect of environmental variables such as soil nutrients [13], salinity $[11,14]$ or a combination of factors [15]. This approach assumes that the boundary line at the outer rim of the data body depicts the functional dependence between a dependent variable (e.g., crop yield) and an independent variable (e.g., soil salinity), and may be of greater interest than the line of best fit through the cloud of data [11]. At the boundary limit, the independent variable is assumed to be the 
main factor limiting the dependent variable, while the effects of other factors are insignificant. In the situations described by the data located below the boundary line, yield is limited by one or more other factors [13, 16]. One weakness of this approach is that the influence of the factors is analyzed one at a time; the method is thus only appropriate if one is interested in the effects of only one or two limiting factors [17].

Our work refers to the effect of waterlogging and salinity on date yield in farmers' field plots located in five sectors of the Wargla basin (Algeria). Despite the high tolerance of date palm [6], an increase in salinity is likely to cause a decrease in date yield [18, 19], particularly in this zone [20]. Two complementary approaches were used to quantify the influence of these factors: variance analysis according to environmental variables previously split into classes; and the boundary line approach. We expected to distinguish the direct effects of the shallow water table and its indirect effect through the increase in soil salinity, and to analyze the predominance or the combined effects of the two factors.

\section{Materials and methods}

\subsection{Study area}

The Wargla basin is located in the lower valley of the Oued Mya in the northeastern Sahara. The Wargla basin has been known since the 6th century for the production and trade of dates. In the Saharan area of Africa, a chott is a lake with a seasonally fluctuating level of saline water and changing shore. It is generally included in a sabkha, which is a larger area of flat saline soil occurring in inland plains with shallow water tables. The palm groves studied were located around such a chott, itself included in a large sabkha. In 2002, the Wargla oasis contained a total of 280605 date palm trees on an area of 1915 ha, with $97.4 \%$ in traditional sectors and $2.6 \%$ in improved irrigation schemes. Planting density ranged between 123 and 147 trees per hectare. Many plots have been abandoned because of the rise in the water table, soil salinization and/or for socioeconomic reasons.

From 1930 on, Algerian policies included the large-scale allocation of fossil groundwater resources to solve recurrent water scarcity. Irrigation water is currently supplied by tube wells that tap deep groundwater resources from the Mio-Pliocene and Senonian aquifers. At field level, irrigation water is distributed to the different irrigation basins by means of one to two irrigation turns per fortnight in winter and two to three irrigation turns per week in summer. A $1.5 \mathrm{~L} \cdot \mathrm{s}^{-1} \cdot \mathrm{ha}^{-1}$ discharge of irrigation water is enough to meet the water requirements of $0.7 \mathrm{~L} \cdot \mathrm{s}^{-1} \cdot \mathrm{ha}^{-1}$ in winter and $1 \mathrm{~L} \cdot \mathrm{s}^{-1} \cdot \mathrm{ha}^{-1}$ in summer.

With the development of artesian wells, the rise in the groundwater level required the rehabilitation and extension of the drainage system. However, drainage was not efficient because outflow was reduced due to poor maintenance of the open drainage collector at the outlet of the system, causing a rise in the water table, and an increase in land salinity [21]. In the central part of the Wargla basin, the water table depth averaged $1.2 \mathrm{~m}$ in 1991 and $1 \mathrm{~m}$ (from $0 \mathrm{~m}$ to $2 \mathrm{~m}$ depending on the altitude and the season) in 1998.

This situation caused soil salinization, local accumulation of salt at the soil surface and even a petrogypsic horizon, which is a cemented horizon containing secondary accumulations of gypsum within the capillary fringe [22]. Petrogypsic horizons frequently occur associated with calcic horizons and can contain secondary carbonates. These gypsum-cemented horizons impede root development and growth of date palm trees, as well as the infiltration of irrigation water [23]. The soils are coarsetextured and range from sand to loamy sand with sand content higher than $70 \%$ in the $0-150 \mathrm{~cm}$ soil layer [20].

\subsection{Data}

A total of 167 field plots containing date palm trees from (15 to 45 ) years old were 


\section{Daddi Bouhoun et al.}

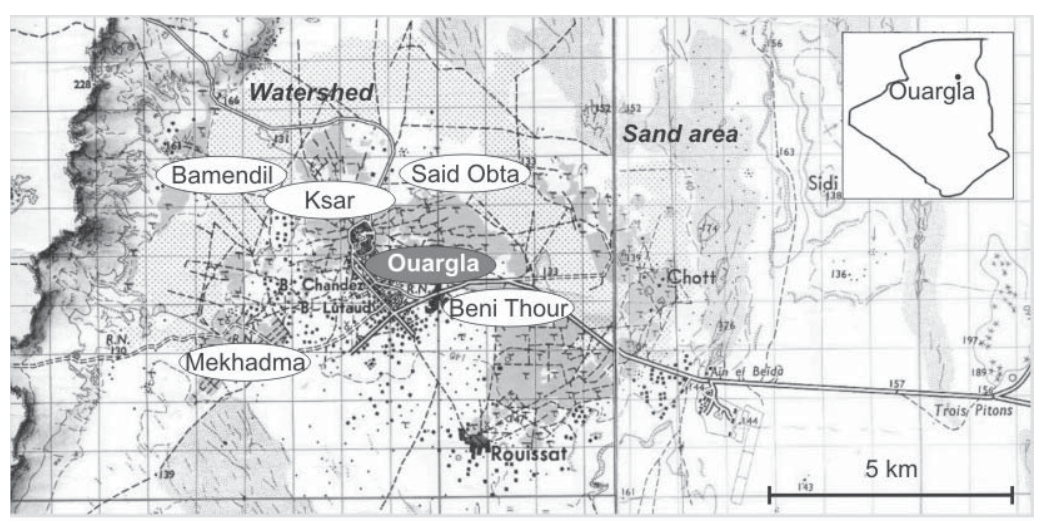

Figure 1.

Date palm sectors surveyed in the Wargla basin (Algeria) to study the combined effects of waterlogging and salinity on fruit yield.

selected in the Bamendil ( 44 plots), Beni (48 plots) and Said Otba (34 plots) irrigation sectors (figure 1). Measurements were made at the end of the harvest stage from DecemThour (16 plots), Ksar (25 plots), Mekhadma ber 2001 to February 2002. During the winter season, the water table was shallow and the low frequency of irrigation events did not significantly affect the representativeness of salinity measurements.

On each plot, three auger holes were randomly drilled to a depth of $1.2 \mathrm{~m}$. Soil samples were collected between a depth of $(0$ and 40$) \mathrm{cm}$, and then dried. Electrical conductivity was measured by the 1:5 soilto-water ratio extract method $\left(\mathrm{EC}_{1: 5}\right)$ because large uncertainty can be associated with the water content of the saturated paste in sandy soils [24]. A highly significant relationship generally exists between $\mathrm{EC}_{1: 5}$ and $\mathrm{EC}_{\mathrm{e}}$ in saturated paste [25], and no significant bias can be introduced since soil texture is very homogeneous. Electrical conductivity and temperature were measured using a Karl-Kolb D 8120 conductimeter, and readings were adjusted to $25^{\circ} \mathrm{C}$ for correct interpretation.

The occurrence and depth of gypsumcemented horizons and the depth of the water table were noted. When the groundwater depth was less than $1.2 \mathrm{~m}$, samples of groundwater were collected for measurement of electrical conductivity $\left(\mathrm{EC}_{\mathrm{w}}\right)$. The electrical conductivity of the irrigation water $\left(E_{\mathrm{i}}\right)$ was measured concomitantly in each irrigation sector. Yields were estimated in terms of date production per tree based on interviews with farmers.

\subsection{Statistical analyses}

The variables were transformed into:

- four classes of water table depth: less than $40 \mathrm{~cm}(\mathrm{P} 1), 40 \mathrm{~cm}$ to $80 \mathrm{~cm}(\mathrm{P} 2), 80 \mathrm{~cm}$ to $120 \mathrm{~cm}$ (P3) and greater than $120 \mathrm{~cm}$ (P4); - four classes of soil salinity $\left(\mathrm{EC}_{1: 5}\right)$ : less than $3 \mathrm{dS} \cdot \mathrm{m}^{-1}$ (S1), (3 to 5) $\mathrm{dS} \cdot \mathrm{m}^{-1}$ (S2), (5 to 7) $\mathrm{dS} \cdot \mathrm{m}^{-1}(\mathrm{~S} 3)$ and above $7 \mathrm{dS} \cdot \mathrm{m}^{-1}(\mathrm{~S} 4)$; - two classes of occurrence of a gypsumcemented horizon within the $0-120 \mathrm{~cm}$ horizon: no presence (C0) and presence (C1).

In the first step, the results were analyzed using one-way analysis of variance (oneway ANOVA) and Fisher's test. The leastsquare means were compared according to Tukey's test at a probability threshold of 5\% for the following variables:

- irrigation water salinity $\left(\mathrm{EC}_{\mathrm{i}}\right)$ according to the irrigation sector;

- water table salinity $\left(\mathrm{EC}_{\mathrm{w}}\right)$ and soil salinity $\left(\mathrm{EC}_{1: 5}\right)$ according to the irrigation sector, class of groundwater depth and occurrence of a gypsum-cemented horizon;

- date palm yield according to the irrigation sector, class of groundwater depth, soil salinity and occurrence of a gypsumcemented horizon.

Ordinary linear regressions were also performed with water table salinity $\left(\mathrm{EC}_{\mathrm{w}}\right)$, soil salinity $\left(\mathrm{EC}_{1: 5}\right)$ and date palm yield as dependent variables, and irrigation water salinity $\left(\mathrm{EC}_{\mathrm{i}}\right)$ as an independent variable.

In the second step, the results were analyzed using general linear models (GLM) of water table salinity $\left(\mathrm{EC}_{\mathrm{w}}\right)$, soil salinity $\left(\mathrm{EC}_{1: 5}\right)$ and date palm yield, and Fisher's test. The GLM allows combining quantitative and qualitative data, and their possible interactions. The GLM incorporated analyses of variance according to the above-mentioned factors for each variable, ordinary linear regression according to irrigation water salinity $\left(\mathrm{EC}_{\mathrm{i}}\right)$ as a covariate, and Fisher's test. The least-square means were compared according to Tukey's test at a probability threshold of 5\%. It was not possible to test two-order interactions because some classes were incomplete.

In the third step, some classes were merged (P1 and $\mathrm{P} 2, \mathrm{P} 3$ and $\mathrm{P} 4, \mathrm{~S} 1$ and $\mathrm{S} 2$, and $\mathrm{S} 3$ and $\mathrm{S} 4$ ) in the GLM to test whether 
date palm yield was also affected by a possible two-order interaction between soil salinity and water table depth.

Data were analyzed using Minitab software (version 15).

\subsection{Boundary line approach}

A boundary line is constructed from a scatter plot between two variables where a line connects the outer rim of the data body. An early method consisted of visually estimating the value of parameters or using the extreme values of the data body [12]. Another method consisted of selecting a subset of data and fitting a boundary line on these data [13-15]. More recently, the boundary lines have been estimated using a statistical approach in which the principle is to define $Y=\mathrm{f}(X)$ as a function satisfying $p[Y<\mathrm{f}(X)]=\alpha$ for all values of $X$ such that $\mathrm{f}(X)$ represents the $\alpha$ th quantile regression of the variable $Y$ [26].

In our study, the method was based on the work of Casanova et al. [15] and Kitchen et al. [11]. Each independent variable was subdivided into classes, and then potential yields were calculated for each as the 95th percentile so that a proportion of $95 \%$ of $Y$ measurements were located under the boundary line. For soil salinity, $\mathrm{EC}_{1.5}$ values were subdivided into eight salinity classes from ( 1 to 9 ) $\mathrm{dS} \cdot \mathrm{m}^{-1}$ by steps of $1 \mathrm{dS} \cdot \mathrm{m}^{-1}$. Depending on the potential yield and on the averaged salinity for each class, two models of yield response to salinity were calibrated:

- a piecewise linear response model characterized by a salinity threshold below which yield was not affected, and above which yield decreased linearly with salinity [3];

- a S-shaped response model [5], whose equation is: $Y(E C)=\mathrm{Y}_{\mathrm{M}} /\left[1+\left(\mathrm{EC} / \mathrm{EC}_{50}\right)^{\mathrm{p}}\right]$ (equation 1).

When $Y_{M}$ is the maximum yield, $E_{50}$ is the electrical conductivity corresponding to a $50 \%$ reduction in yield and $p$ is a parameter of curvature.

The water table depth was first split between the water table depths greater than $120 \mathrm{~cm}$ (deep water table), and the water table depths smaller than $120 \mathrm{~cm}$ (shallow water table). For the shallow water table group, the water table depth values were subdivided into five classes from (20 to 120) $\mathrm{cm}$ by steps of $20 \mathrm{~cm}$, and the yield response to water table depth was calibrated according to the S-shaped model (equation 1). The potential yields were also calculated for the deep water table and the two gypsum-cemented horizon classes. The boundary lines were thus defined as discontinuous functions.

The limiting factor was identified and the potential yield $\left(\mathrm{Y}_{\mathrm{p}}\right)$ of each plot was calculated as the minimum value of different responses of date palm yield according to the soil salinity, the water table depth, and the occurrence of a gypsum-cemented horizon. No limiting factor was considered when potential yield was less than $10 \%$ below maximum yield.

The yield gap was calculated for each plot as the difference between potential yield $\left(\mathrm{Y}_{\mathrm{p}}\right)$ and actual yield $\left(\mathrm{Y}_{\mathrm{a}}\right)$. A general linear model (GLM) of the yield gap was finally performed according to the sector, water table depth class, soil salinity class and gypsum-cemented horizon class, with irrigation water salinity as a covariate.

\section{Results}

\subsection{Environmental constraints}

Measurements of irrigation water salinity ranged between (1.7 and 6 ) dS $\mathrm{m}^{-1}$ depending on the irrigation sector. Bamendil $\left(2.16 \mathrm{dS} \cdot \mathrm{m}^{-1}\right)$ and Mekhadma $\left(2.53 \mathrm{dS} \cdot \mathrm{m}^{-1}\right)$ were the least saline, followed by Ksar $\left(3.48 \mathrm{dS} \cdot \mathrm{m}^{-1}\right)$, Beni Thour $\left(3.70 \mathrm{dS} \cdot \mathrm{m}^{-1}\right)$ and Said Otba, where average salinity reached $4.24 \mathrm{dS} \cdot \mathrm{m}^{-1}$ (table I).

The occurrence of a gypsum-cemented horizon between a depth of $(0$ and 120) $\mathrm{cm}$ was observed in $13.8 \%$ of the field plots (table I). It was observed in the Mekhadma, Ben Thour, Ksar and Bamendil sectors in $20.8 \%, 18.7 \%, 16 \%$ and $13.6 \%$ of the field plots, respectively. No gypsum-cemented horizon was observed in the Said Otba sector. 


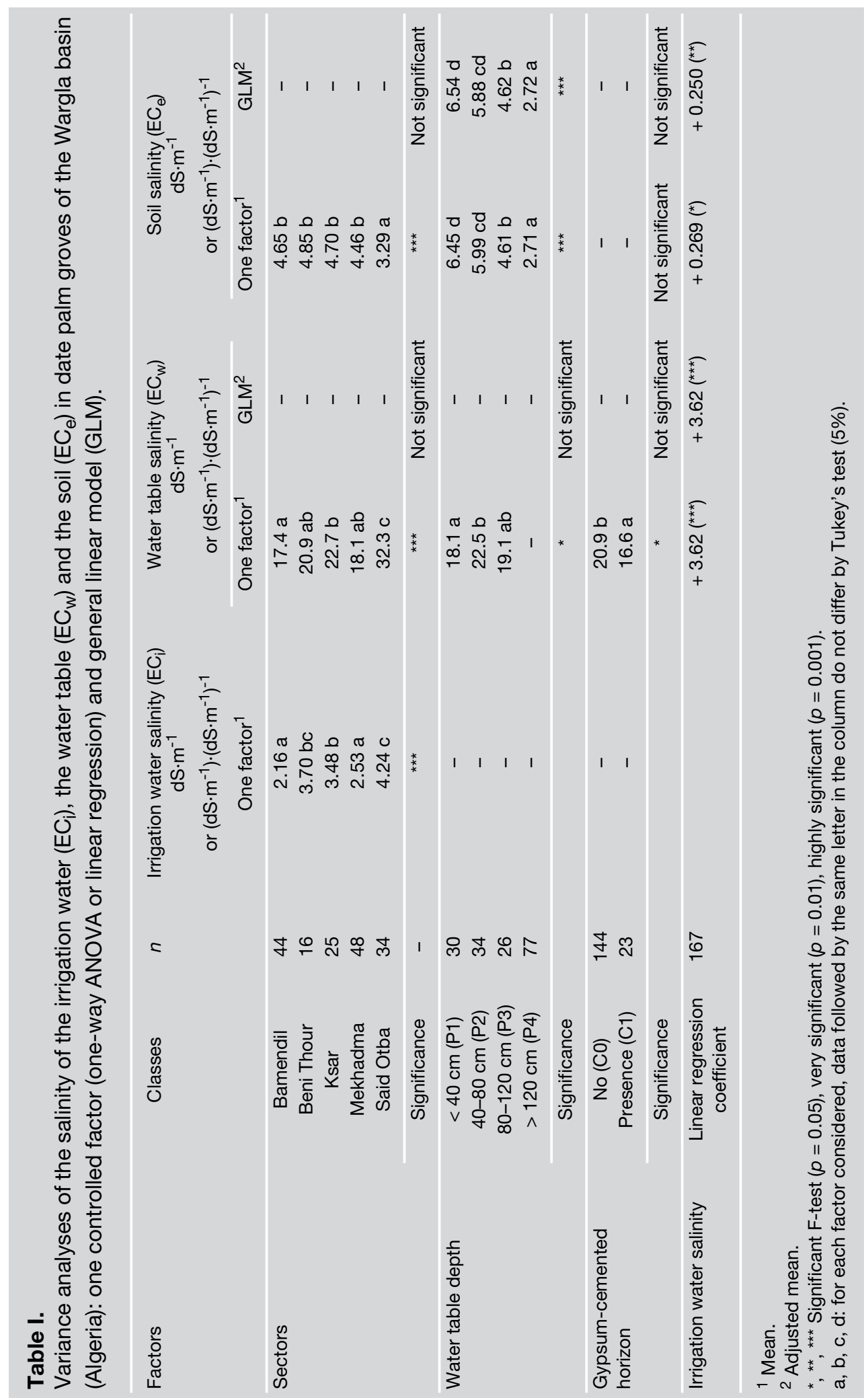


A deep water table exceeding $120 \mathrm{~cm}$ (P4) was observed in $46.1 \%$ of the field plots. The water table was considered to be shallow in, respectively, $17.9 \%, 20.4 \%$ and $15.6 \%$ of plots where the water table was between $29 \mathrm{~cm}$ (minimum value) and $40 \mathrm{~cm}$ (P1), 40 and $80 \mathrm{~cm}$ (P2) and 80 and $120 \mathrm{~cm}$ (P3) (table I). Among the sectors, there was a very high proportion of deep water tables in the Said Otba sector $(82.3 \%$ of water tables at a depth of more than $120 \mathrm{~cm}$ ), as opposed to a high proportion of shallow water tables in the Bamendil (38.6\% of water tables at a depth of less than $40 \mathrm{~cm}$ ) and Mekhadma (62.5\% of water tables at a depth of less than $120 \mathrm{~cm}$ ) sectors.

The electrical conductivity of the shallow water tables was very high, ranging from (10 to 39.7$) \mathrm{dS} \cdot \mathrm{m}^{-1}$ with a median value of $18.4 \mathrm{dS} \cdot \mathrm{m}^{-1}$. Groundwater salinity was mainly affected by irrigation water salinity. No significant effects of the irrigation sector, of the occurrence of gypsum-cemented horizons, or of water table depth were observed on groundwater salinity in the GLM (table I). Electrical conductivity of the water table was not significantly correlated with the water table depth.

Electrical conductivity of 1:5 soil extract ranged from (1.1 to 9.76) $\mathrm{dS} \cdot \mathrm{m}^{-1}$ with a median value of $3.96 \mathrm{dS} \cdot \mathrm{m}^{-1}$. Field plot percentages of $28.7 \%, 35.9 \%, 23.4 \%$ and $12.0 \%$ were characterized by $\mathrm{EC}_{1.5}$ lower than $3 \mathrm{dS} \cdot \mathrm{m}^{-1}$ (S1), from ( 3 to 5$) \mathrm{dS} \cdot \mathrm{m}^{-1}(\mathrm{~S} 2)$, from ( 5 to 7$) \mathrm{dS} \cdot \mathrm{m}^{-1}(\mathrm{~S} 3)$, and greater than $7 \mathrm{dS} \cdot \mathrm{m}^{-1}(\mathrm{~S} 4)$, respectively (table I). $\mathrm{EC}_{1: 5}$ was significantly correlated with irrigation water salinity, water table depth (table I), and the electrical conductivity of the water table $\left(\mathrm{EC}_{\mathrm{w}}\right)$. The average $\mathrm{EC}_{1: 5}$ values increased from $2.71 \mathrm{dS} \cdot \mathrm{m}^{-1}$ for the deep water table ( $\mathrm{P} 4)$ to, respectively, $4.61 \mathrm{dS} \cdot \mathrm{m}^{-1}, 5.99 \mathrm{dS} \cdot \mathrm{m}^{-1}$ and $6.45 \mathrm{dS} \cdot \mathrm{m}^{-1}$ for water table depths of between (80 and 120) $\mathrm{cm}(\mathrm{P} 3)$, (40 and 80) $\mathrm{cm}(\mathrm{P} 2)$ and less than $40 \mathrm{~cm}(\mathrm{P} 1)$ (table I). $\mathrm{EC}_{\mathrm{W}}$ to $\mathrm{EC}_{1: 5}$ ratios decreased from 4.24 to 3.83 and 2.88 for water table depths of between (80 and 120) $\mathrm{cm}$ (P3), (40 and 80) cm (P2) and less than $40 \mathrm{~cm}$ (P1), respectively. This strong dependence between water table depth and soil salinity led us to merge classes to test for possible interactions of these factors. Among the sectors, we noted in particular:

- a large proportion of highly saline soils ( $22.7 \%$ of soil salinity greater than $7 \mathrm{dS} \cdot \mathrm{m}^{-1}$ ) in the Bamendil sector in relation to the shallow water table, despite the low salinity of irrigation water;

- a large proportion of weakly saline soils ( $58.8 \%$ of soil salinity less than $3 \mathrm{dS} \cdot \mathrm{m}^{-1}$ ) in the Said Otba sector in relation to the deep water table, despite the high salinity of irrigation water.

There was no significant effect of the irrigation sector or of the occurrence of a gypsum-cemented horizon on soil salinity.

\subsection{Mean date palm yield according to environmental stresses}

Date yields ranged from (15.7 to 98) $\mathrm{kg} \cdot \mathrm{tree}^{-1}$ with a median value of $55.3 \mathrm{~kg} \cdot$ tree $^{-1}$. In both one-way analyses of variance and the general linear model (GLM), date yield was influenced by the irrigation sector, the water table depth, the occurrence of a gypsumcemented horizon, and the soil salinity (table II). Date yield significantly decreased with an increase in irrigation water salinity in linear regression. Date yield was also significantly correlated with the water table depth, and the electrical conductivity of the shallow water table and of the soil. In the GLM, irrigation water salinity did not influence date yield due to high correlation with both soil salinity and the irrigation sector.

Our results allowed us to distinguish three groups of irrigation sectors (table II). The yields in the Mekhadma sector were the highest, with an average yield of $69.9 \mathrm{~kg} \cdot$ tree $^{-1}$. In the Bamendil sector, yields were significantly lower than in the Mekhadma sector, with an average yield of $56.5 \mathrm{~kg} \cdot \mathrm{tree}^{-1}$. The satisfactory yields of these two sectors located in the western Wargla basin were achieved despite high soil salinity and a shallow water table, but with low irrigation water salinity. In the Said Otba, Ksar and Beni Thour sectors located in the eastern Wargla basin, the yields were significantly lower, with average yields of (51.1, 41.8 and 34.3) $\mathrm{kg} \cdot$ tree $^{-1}$, respectively. The Beni Thour 
M. Daddi Bouhoun et al.

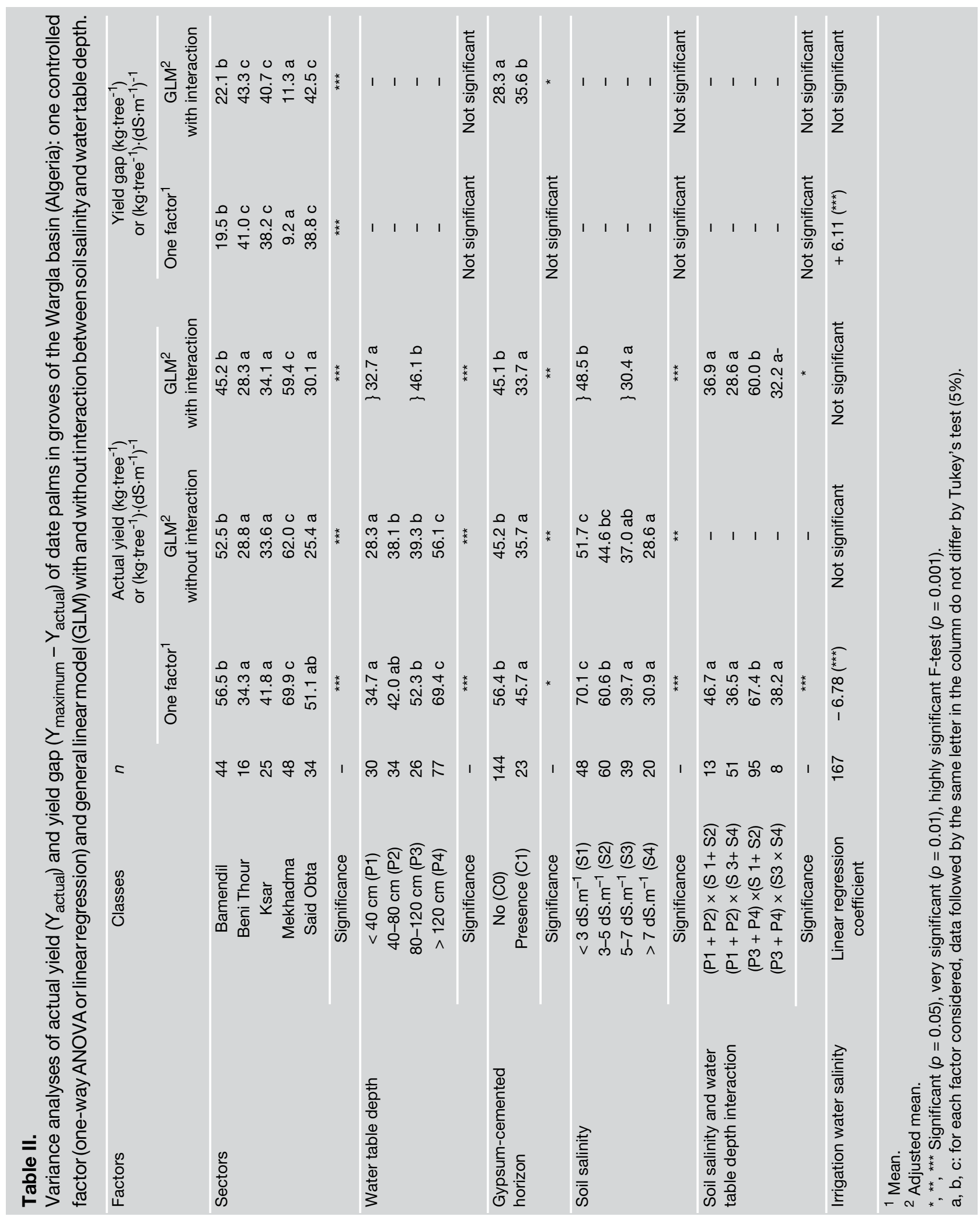


and Ksar sectors were characterized by high soil salinity but medium water table depth and irrigation water salinity, while the Said Otba sector had saline irrigation water, a deep water table and low soil salinity.

Water table depth and soil salinity significantly affected date yield (table II). Date yield increased from $34.7 \mathrm{~kg} \cdot$ tree $^{-1}$ with a shallow water table (less than $40 \mathrm{~cm}$ ), to $69.4 \mathrm{~kg} \cdot$ tree $^{-1}$ with a deep water table (deeper than $120 \mathrm{~cm}$ ). In the same way, date yield increased from $30.9 \mathrm{~kg} \cdot \mathrm{tree}^{-1}$ with highly saline soil (greater than $7 \mathrm{dS} \cdot \mathrm{m}^{-1}$ ) to $70.1 \mathrm{~kg} \cdot$ tree $^{-1}$ for weakly saline soil (less than $\left.3 \mathrm{dS} \cdot \mathrm{m}^{-1}\right)$. When we tested for an additional two-order interaction between water table depth and soil salinity, date yields were significantly higher when the water table was deeper than $80 \mathrm{~cm}$ and soil salinity was less than $5 \mathrm{dS} \cdot \mathrm{m}^{-1}$ than when the water table was shallow or the soil was highly saline (table II). At the same time, there were no significant effects of soil salinity when the water table was shallow and no significant effect of water table depth when salinity was high. No other two-order interaction was significant.

The occurrence of a gypsum-cemented horizon caused a significant decrease in date yield from (56.4 to 45.7$) \mathrm{kg} \cdot \mathrm{tree}^{-1}$ (table II).

\subsection{Potential date palm yield according to environmental stresses}

When date palm yield is plotted against $\mathrm{EC}_{1: 5}$ (figure 2), both piecewise linear response and S-shaped response models show highly significant adjustments between soil salinity and potential yield. For the piecewise linear response model, the adjusted parameters were a maximum yield of $96.1 \mathrm{~kg} \cdot \mathrm{tree}^{-1}$, a threshold salinity of $4.29 \mathrm{dS} \cdot \mathrm{m}^{-1}$ and a linear decrease in yield beyond the threshold of $12.5 \mathrm{~kg} \cdot$ tree $^{-1}$. For the $\mathrm{S}$-shaped response model, the adjusted parameters according to equation 1 were a maximum yield of $97.8 \mathrm{~kg} \cdot \mathrm{tree}^{-1}$ and a salinity value of $8.05 \mathrm{dS} \cdot \mathrm{m}^{-1}$, corresponding to a $50 \%$ reduction in yield and a parameter of curvature $p$ of 3.98. The S-shaped response model was selected for the remainder of the study.

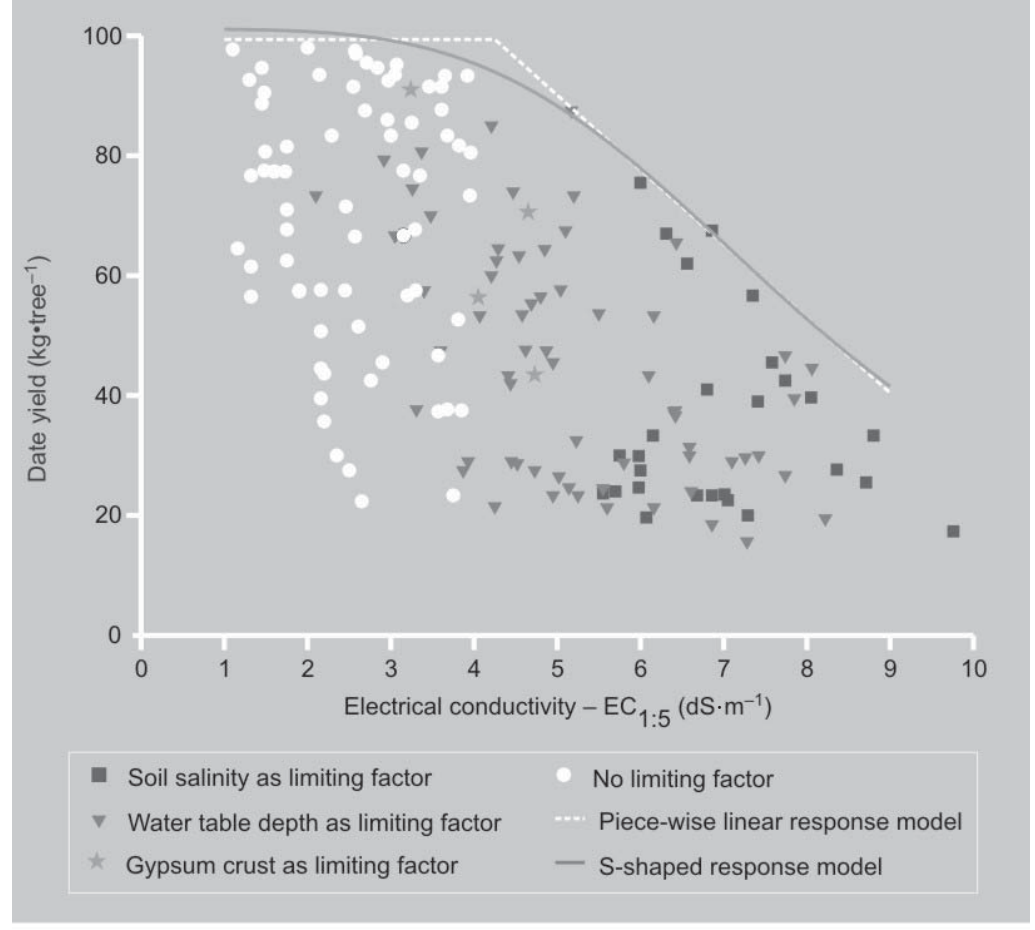

A water table depth greater than $120 \mathrm{~cm}$ Figure 2. was considered as not limiting, and the maximum yield was calculated as $96.5 \mathrm{~kg} \cdot \mathrm{tree}^{-1}$. When date palm yield is plotted against water table depth for water table depths lower than $120 \mathrm{~cm}$ (figure 3), the S-shaped response models show a significant adjustment between water table depth and potential yield (figure 3). The adjusted parameters according to equation 1 were a maximum yield of $80.0 \mathrm{~kg} \cdot$ tree $^{-1}$ and a depth value of $29.3 \mathrm{~cm}$, corresponding to a $50 \%$ reduction in yield and a parameter of curvature $p$ of 9.12. This model of yield response to water table depth was selected for the remainder of the study.

Potential date palm yield was decreased to $83.4 \mathrm{~kg} \cdot$ tree $^{-1}$ in the presence of a gypsum-cemented horizon.

Potential yield was then calculated for each field plot as the minimum value of the potential yield according to soil salinity, water table depth and occurrence of a gypsum-cemented horizon. No limiting factor was considered when potential yield was less than 10\% under maximum yield for 71 field plots $(42.5 \%$ of the sample).
Relation between soil salinity and actual date palm yields, main limiting factors $(n=167$ field plots), and relation between soil salinity and potential date palm yield according to the piecewise linear response model [6] and the S-shaped response model [10]. 


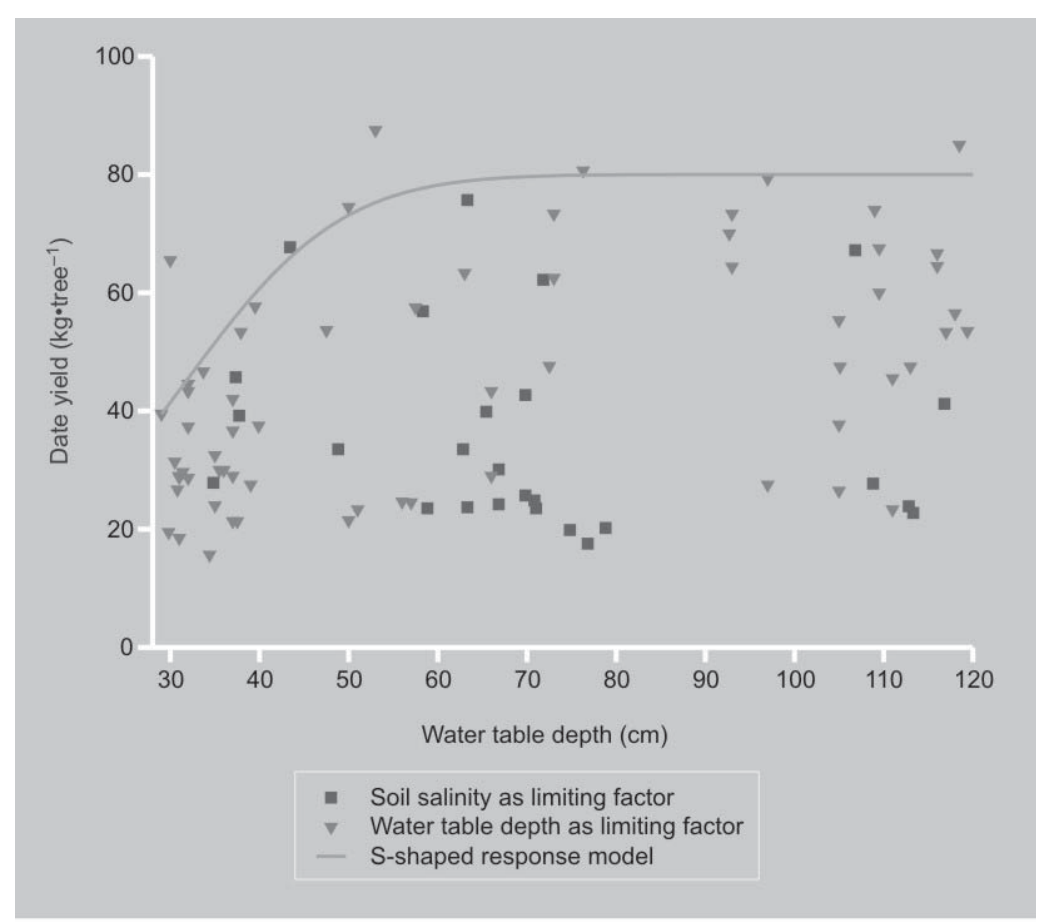

Figure 3.

Relation between water table depths lower than $120 \mathrm{~cm}$ and actual date palm yields, main limiting factors $(n=90$ field plots), and relation between water table depth and potential date palm yield according to the S-shaped response model [10].
The limiting factor was soil salinity for 28 field plots (16.8\%), water table depth for 64 field plots $(38.3 \%)$, including 22 field plots (13.2\%) limited by a very shallow water table (less than $40 \mathrm{~cm}$ ), and occurrence of a gypsum-cemented horizon for 4 field plots $(2.4 \%)$ (figure 2 ).

The yield gap was then calculated for each plot as the difference between the potential and actual yield. Variance analysis showed a significant influence of the irrigation sector and irrigation water salinity, while the influence of soil salinity and of water table depth was not significant (table II). Actual yields were very close to potential yields according to the model in the Mekhadma sector and satisfactory in the Bamendil sector, where average yield gaps were only (9.2 and 19.5) kg.tree ${ }^{-1}$, respectively. The yield gap reached $40 \mathrm{~kg} \cdot \mathrm{tree}^{-1}$ in the Beni Thour, Ksar and Said Otba sectors. In the GLM, irrigation water salinity did not influence the yield gap due to high correlation with the irrigation sector. The yield gap was also independent of soil salinity or water table depth, but was affected by the occurrence of a gypsum-cemented horizon (table II).

\section{Discussion and conclusion}

\subsection{Causes of soil salinity}

The irrigation sectors were mainly differentiated by the degree of salinity of the irrigation water, which increased from the west to the east of the Wargla basin. Salinity of the irrigation water was the main cause of groundwater salinity, with no significant effect of the depth of the water table.

Irrigation water salinity and water table depth were the main sources of variation in soil salinity. Shallow groundwater is expected both to reduce leaching capacity and to encourage capillary rise between irrigation events. Our results corroborate those of a previous study in the Wargla oasis, which showed an increase in capillary rise and salinity with increasing evaporative demand where the water table was shallow [27]. Similarly, in Sidi Mahdi, in southeastern Algeria, an experiment showed that salt accumulation decreased from $(5$ to 0.5) $\mathrm{t} \cdot \mathrm{ha}^{-1} \cdot \mathrm{y}^{-1}$ when the water table depth increased from (40 to 90) $\mathrm{cm}$ [28].

It is noteworthy that soil salinity differed only slightly between the irrigation sectors in spite of marked variations in irrigation and groundwater salinity. In the Bamendil and Mekhadma sectors, soil salinity reached relatively high values in relation to a shallow water table, despite the low salinity of irrigation water. In contrast, the low soil salinity measured in the Said Otba sector resulted from a deeper water table and probably more efficient drainage, despite the high salinity of irrigation water.

In the Wargla basin, the high discharge and frequent application of irrigation water did not limit water availability. Thus, leaching was predominantly restrained by the reduced outflow due to the low slope at the border of the chott, inefficient drainage and poor maintenance of the open drainage collector at the outlet of the system, as was assessed in similar conditions in Tunisia [29]. The enhancement of the drainage system should be the major way to control both waterlogging and salinity better. 


\subsection{Influence of environmental constraints on date palm yield}

Variance analysis and the boundary line approach provided similar results with respect to the effect of different environmental constraints on date palm yield. Analysis of variance allowed us to highlight combined and significant effects of water table depth, soil salinity and the occurrence of a gypsum-cemented horizon on mean date yield, but also differences between palm grove sectors. The boundary line approach provided consistent results when the potential yield decreased with an increase in soil salinity, a decrease in water table depth or the occurrence of a gypsumcemented horizon.

Variance analysis also emphasized the effect of interaction between water table depth and soil salinity on date palm yield. The effect of soil salinity was shown to be not significant when the groundwater was shallow. Similarly, the effect of water table depth was shown to be not significant when soil salinity was high. This result is consistent with the theory of limiting factors explaining plant behavior under combined stresses, and corroborates the conclusion of Shani et al. [18] and Tripler et al. [19] on date palm. They concluded that growth response under salinity, combined with water or nitrate (growth promoters) or with boron (growth inhibitor), behaved according to the dominant of the two stress-causing factors and did not show additive effects. However, a response curve based on the adjustment in the cloud of points is not appropriate in the real conditions encountered in farmers' fields where yield results not only from environmental constraints but also from farmers' practices. At the boundary line, the independent variable is assumed to be the main limiting factor and allows the functional dependencies between environmental stresses and yield to be depicted. The combination of variance analysis and the boundary line approach proved to be helpful in farmers' field conditions where actual yields could be far below potential yields, allowing us to identify the main limiting factor of date palm yield for each field plot.
Given that this crop is so tolerant to salinity, waterlogging was considered as the main limiting factor of date palm yield for $38 \%$ of the field plots. Potential date palm yield decreased to $80 \mathrm{~kg} \cdot$ tree $^{-1}$ when the water table was shallow (depth between [(50 and 120) $\mathrm{cm}]$ during the winter season, and dropped faster when the water table was very shallow (less than $50 \mathrm{~cm}$ deep). The date palm requires a well-aerated soil with a water table comprised between (1.2 and 1.5) $\mathrm{m}$ depth for maximum yields [30]. In soils with inadequate aeration, the lack of oxygen results in reduced plant growth and diminished productivity for many reasons, including reduced root growth and root size, and subsequent reduced ability of roots to absorb minerals and water from the soil. In the Wargla basin, a water table deeper than $130 \mathrm{~cm}$ was recommended by Dubost [28] and could only be achieved with a more efficient drainage system and appropriate maintenance of the open drainage collector at the outlet of the system. At field level, a supply of sand and manure was also suggested to reduce the effects of waterlogging and salinity in accordance with certain farmers' practices [27].

Despite high salinity levels, soil salinity was the main limiting factor for only $17 \%$ of the field plots. The boundary line approach specifically allowed us to establish a relationship between soil salinity and potential date palm yield in the real conditions encountered in farmers' fields, which is consistent with commonly accepted models. Maximum date palm yield was confirmed to be very close to $100 \mathrm{~kg}$ of dates per tree. Yield was affected from an electrical conductivity of $1: 5$ solution extract $\left(\mathrm{EC}_{1: 5}\right)$ of $4.3 \mathrm{dS} \cdot \mathrm{m}^{-1}$ and reached only half-maximum yield for $\mathrm{EC}_{1: 5}$ of $8 \mathrm{dS} \cdot \mathrm{m}^{-1}$. According to many relations established for the estimation of the electrical conductivity of saturation extracts from the electrical conductivity of 1:5 soil / water suspensions, e.g., [24, 25], including similar coarse-textured soils with gypsum [31], or even considering the electrical conductivity of the water table as a proxy, the threshold values would be much higher than those established by FAO [6] for date palm. However, these relations are location-specific and can hardly be reliably 


\section{Daddi Bouhoun et al.}

extrapolated. Moreover, substantial errors may occur with soils containing gypsum because gypsum solubility close to $2 \mathrm{~g} \cdot \mathrm{L}^{-1}$ or $3 \mathrm{dS} \cdot \mathrm{m}^{-1}$ is liable to affect the estimation of the soluble salt content with a decreasing soil-to-water ratio.

Yield was also sometimes limited by the occurrence of a gypsum-cemented horizon. However, while the model allowed us to account for the effect of soil salinity and groundwater depth on potential date palm yield in the Wargla basin, the yield gap remained dependent on the occurrence of a gypsum-cemented horizon, although this factor was also taken into account in the model. This result illustrates the limitations of the method evoked by Lark when more than two limiting factors are taken into consideration [17].

The yield gap ultimately depended on the date palm grove sector, as actual yield remained below potential yield in certain sectors. Date palm yield was satisfactory in the Bamendil and Mekhadma sectors, but the yield gap increased up to $40 \mathrm{~kg}$ of dates per tree in the Beni Thour, Ksar and Said Otba sectors where irrigation water is the most saline. Independently of, and in addition to, the effect of soil salinity, irrigation water salinity could thus limit date palm yield.

Possible causes could also involve other factors that were not taken into account in the present study, such as agricultural practices and local know-how concerning the management of the date palm grove, or socio-economic causes liable to affect farmers' strategies. In the Wargla basin, some farmers are actually poorly committed and extensively manage their date palm plantation with date yield of only $20 \mathrm{~kg}$ of dates per tree, even without environmental constraints, while some other efficient farmers can achieve high yield very close to potential yield. Our report confirms the helpfulness of the boundary line approach in farmers' field conditions.

\section{References}

[1] Smedema L.K., Shiati K., Irrigation and salinity: a perspective review of the salinity hazards of irrigation development in the arid zone, Irrig. Drain. Syst. 16 (2002) 161-174.

[2] Postel S., Pillar of sand: can the irrigation miracle last? W.W. Norton \& Co., N.Y., U.S.A., 1999, $320 \mathrm{p}$.

[3] Maas E.V., Hoffman G.J., Crop salt tolerance: current assessment, J. Irrig. Drain. Div. 103 (1977) 115-134.

[4] Maas E.V., Crop salt tolerance, in: Tanji K.K. (Ed.), Agricultural salinity assessment and management, Am. Soc. Civil Eng., N.Y., U.S.A., 1990 .

[5] van Genuchten M.T., Gupta S.K., A reassessment of the crop tolerance response function, J. Indian Soc. Soil Sci. 41 (1993) 730-737.

[6] Ayers R.S., Westcot D.W., Water quality for agriculture, Irrig. Drain. pap., FAO, Rome, 1985.

[7] Munns R., Genes and salt tolerance: bringing them together, New Phytol. 167 (2005) 645-663.

[8] Kijne J.W., Water productivity under saline conditions, in: Kijne J.W., Barker R., Molden D. (Eds.), Water productivity in agriculture: limits and opportunities for improvement, CABI Publ., Wallingford, U.K., 2003.

[9] Shani U., Dudley L.M., Field studies of crop response to water and salt stress, Soil Sci. Soc. Am. J. 65 (2001) 1522-1528.

[10] Zeng L., Shannon M.C., Lesch S.M., Timing of salinity stress affects rice growth and yield components, Agric. Water Manag. 48 (2001) 191-206.

[11] Kitchen N.R., Drummond S.T., Lund E.D., Sudduth K.A., Buchleiter G.W., Soil electrical conductivity and topography related to yield for three contrasting soil-crop systems, Agron. J. 95 (2003) 483-495.

[12] Webb R.A., Use of the boundary line in the analysis of biological data, J. Hortic. Sci. 47 (1972) 309-319.

[13] Lewandowski I., Schmidt U., Nitrogen, energy and land use efficiencies of miscanthus, reed canary grass and triticale as determined by the boundary line approach, Agr. Ecosyst. Environ. 112 (2006) 335-346.

[14] Johnson C.K., Mortensen D.A., Wienhold B.J., Shanahan J. F., Doran J.W., Site-specific management zones based on soil electrical conductivity in a semiarid cropping system, Agron. J. 95 (2003) 303-315. 
[15] Casanova D., Goudriaan J., Bouma J., Epema G. F., Yield gap analysis in relation to soil properties in direct-seeded flooded rice, Geoderma 91 (1999) 191-216.

[16] Milne A.E., Ferguson R.B., Lark R.M., Estimating a boundary line model for a biological response by maximum likelihood, Ann. Appl. Biol. 149 (2006) 223-234.

[17] Lark R.M., An empirical method for describing the joint effects of environmental and other variables on crop yield, Ann. Appl. Biol. 131 (1997) 141-159.

[18] Shani U., Ben-Gal A., Dudley L.M., environmental implications of adopting a dominant factor approach to salinity management, J. Environ. Qual. 34 (2005) 1455-1460.

[19] Tripler E., Ben-Gal A., Shani U., Consequence of salinity and excess boron on growth, evapotranspiration and ion uptake in date palm (Phoenix dactylifera L., cv. Medjool), Plant Soil 297 (2007) 147-155.

[20] Hamdi-Aissa B., Le fonctionnement actuel et passé des sols du nord Sahara (cuvette de Ouargla). Approches micromorphologique, géochimique, minéralogique et organisation spatiale, INA, Paris, France, 2001, 307 p.

[21] Côte M., Des oasis malades de trop d'eau, Sécheresse 9 (1998) 123-130.

[22] Anon., World reference base for soil resources 2006, World Soil Res. Rep., FAO, Rome, Italy, 2006.

[23] Dutil P., Contribution à l'étude des sols et paléosols du Sahara, Univ. Louis Pasteur, Strasbg., France, 1971, 346 p.
[24] Slavich P.G., Petterson G.H., Estimating the electrical conductivity of saturated paste extracts from 1:5 soil, water suspensions and texture, Aust. J. Soil Res. 31 (1993) 73-81.

[25] Chi C.-M., Wang Z.-C., Characterizing saltaffected soils of Songnen plain using saturated paste and 1:5 soil-to-water extraction methods, Arid Land Res. Manag. 24 (2010) $1-11$.

[26] Makowski D., Doré T., Monod H., A new method to analyse relationships between yield components with boundary lines, Agron. Sustain. Dev. 27 (2007) 119-128.

[27] Daddi Bouhoun M., Brinis L., Étude de la dynamique des sels solubles dans un sol irrigué gypso-salin : cas d'une palmeraie de la cuvette de Ouargla, J. Alger. Reg. Arid. (2006) 17-20.

[28] Dubost D., Écologie, aménagement et développement agricole des oasis algériennes, Univ. François Rabelais, Tours, France, 1991, $550 \mathrm{p}$.

[29] Marlet S., Bouksila F., Bahri A., Water and salt balance at irrigation scheme scale: A comprehensive approach for salinity assessment in a Saharan oasis, Agric. Water Manag. 96 (2009) 1311-1322.

[30] Munier P., Le palmier-dattier, G.-P. Maisonneuve \& Larose, Paris, France, 1973.

[31] Khorsandi F., Yazdi F.A., Gypsum and texture effects on the estimation of saturated paste electrical conductivity by two extraction methods, Commun. Soil Sci. Plant Anal. 38 (2007) 1105-1117. 


\section{Investigar los efectos combinados de anegamiento y la salinidad sobre la rendimiento de palma Ouargla Cuenca, Argelia.}

Resumen - Introducción. Mientras que los investigadores han pagado muy cerca atención al efecto de la salinidad del suelo en los rendimientos de los cultivos, los obstáculos metodológicos, cuando la salinidad se combina con otros factores crecimiento, especialmente en el lugar. Una metodología específica se ha adaptado para evaluar el efecto del anegamiento y la salinidad sobre el rendimiento de la palma datilera (Phoenix dactylifera L. cv. Deglet Nour). Material y métodos. El rendimiento de de la palma datilera, la profundidad del agua subterránea, agua de riego, el agua las aguas subterráneas y la salinidad del suelo se midieron en 167 parcelas ubicadas en cinco áreas de la cuenca de riego de Ouargla (Argelia). Un análisis de varianza y enfoque de frontera se combinaron para evaluar el rendimiento real y potenciales en términos de las limitaciones medioambientales. Resultados y discusión. La alta salinidad del suelo resultante de agua de riego y de agua salina subterránea tabla es poco profundo. El rendimiento real disminuyó con el aumento salinidad del suelo, reduciendo la profundidad del agua y la presencia de un horizonte compacto de yeso en el suelo. El efecto significativo de la interacción entre profundidad de las aguas subterráneas y la salinidad del suelo mostraron que la cultura respondieron más a la tensión que la combinación de efectos individuales. La potencial de rendimiento se evaluó sobre la base de clases de nivel freático agua, la salinidad del suelo y la presencia de horizonte de yeso compacto. La relación entre la salinidad del suelo y el potencial de rendimiento ha sido punto de referencia dos modelos. Los factores limitantes fueron, en orden de importancia, disminución de las aguas subterráneas poco profundas $(38,3 \%$ de las parcelas de estudio), la salinidad del suelo de alta (16,8\%) y la presencia de un horizonte compacto de yeso (2,4\%); no había ningún factor limitante para el 42,5\% de las parcelas. En algunas zonas, rendimientos reales se mantuvo muy por debajo de los rendimientos potenciales y el efecto la salinidad del agua de riego adicionales podrían ser considerados.

Argelia / Phoenix dactylifera / rendimiento / anegamiento / salinidad del suelo 